\title{
Sverige - Polen. 1000 år av krig og kärlek
}

\author{
Herman Lindquist i samarbete med Liliana Komorowska-Lindquist \\ Stockholm: Albert Bonniers Förlag 2019 \\ 544 sider. ISBN 9789100178208
}

Omtalt av Karl-Erik Frandsen [Docent emeritus, dr.phil., Saxo-instituttet ved Københavns Universitet, frandsen@hum.ku.dk]

Herman Lindqvist er født i Helsingfors og har en lang karriere bag sig som journalist og udenrigskorrespondent i hele verden. Siden 1991 har han været fuldtidsforfatter og formidler af historie, især vedrørende Nordens og Polens historie i nyere tid. Han har ikke ligget meget på sofaen, for han er forfatter til ikke mindre end 63 bøger om emner indenfor disse felter, samt energisk formidler af historie i TV og radio. Herman Lindqvists bog om Sveriges og især Polens historie giver et fantastisk billede af, hvordan polakkerne har lidt og kæmpet næsten permanent igennem de sidste 350 år i langt højere grad end de nordiske folk. Han skriver et godt og let læseligt sprog, selv for en dansker, og han lægger målrettet tyngden på skildringen af personer, der har påvirket historien, især konger, dronninger, fyrster, generaler med videre, i Polen. Det er nok også derfor, at den store bog er forsynet med et godt personregister, men til gengæld mangler der et sags- og et stedregister. Det havde nu også været godt med nogle oversigter over slægterne samt nogle kort over de store slag. Fortællingen suppleres af mange gode illustrationer i form af historiemalerier med fyldige undertekster. Uden at det skal opfattes negativt, skal jeg dog også fremhæve, at forfatteren ikke er interesseret i arkæologi og demografi, herunder epidemiologi og økonomisk historie, men det er klart, at når man skal skrive to landes historie igennem 1000 år på 544 sider, kan man selvfølgelig ikke få alle aspekter med.

En af de første afgørende begivenheder i Polens historie, som Lindquist med rette fremhæver, er at Polens første konge Mieszko blev døbt i 966 af missionærer fra Rom, således at Polen blev direkte underlagt paven og ikke det tysk-romerske rige (kejseren). Noget, der har haft politiske og religiøse konsekvenser op til vore dage. Han fremhæver også, at Polen samfundsmæssigt udviklede sig hurtigere end Sverige (og Danmark). I Polen grundlagdes klostre og byer, ligesom katedraler, slotte og kirker blev bygget af sten, længe inden dette skete i Sverige (s. 25). Det siges således om Kazimierz Wielki (den Store) fra kongeslægten Piast, at han overtog et rige af træ, men efterlod et rige af sten. 
Herman Lindquist fremhæver mange steder i bogen, at jøderne havde en særlig stilling i Polen lige til 1943. Der blev således i 1264 udstedt en kongelig forordning, der gav landets jøder religionsfrihed, retten til at bosætte sig og lighed for loven sammen med andre indbyggere. En af konsekvenserne blev, at Polen i middelalderen rummede Europas største jødiske befolkning, hvilket fik meget gunstig betydning for handel og bankvæsen. Bagsiden af medaljen viste sig dog allerede i begyndelsen af 1400-tallet, da der for første gang var en stor pogrom i Krakow. Det skal lige nævnes, at omkring 1935 var der 370.000 jøder i Warszawa, hvilket var den største jødiske by i verden. Men 10 år efter så det helt anderledes ud.

Helt afgørende for Polens historie var personalunionen mellem Polen og Litauen i 1386, da Jadwiga af Polen indgik ægteskab med storfyrst Władisław Jagiełło af Litauen. Den nye statsdannelse stod sin prøve ved det store slag mod Den tyske Orden i 1410 ved Grunwald (Tannenberg), som blev et klart tysk nederlag. Unionen blev omdannet til en virkelig realunion i 1569, da de to landes parlamenter $i$ byen Lublin enedes om en fælles forfatning med en fælles Sejm (rigsdag) og en valgt konge. Forfatningen havde den store svaghed, at en enkelt adelsmand kunne forhindre gennemførelsen af et lovforslag »liberum veto«, og de hyppige valg af nye konger ikke mindst fra Sverige og Sachsen gav tit voldsomme interne stridigheder, som nabomagterne gerne blandede sig i.

Den første af de skrækkelige katastrofer, som i de næste 100 år ramte Polen, var svenskernes invasion under Karl X Gustav i 1655 i et forsøg på at gøre Østersøen til et svensk indhav. Det lykkedes faktisk for svenskerne at erobre de centrale dele af Polen under ufattelige hærgninger, hvorfor årene i polsk litteratur kaldes for "Potop" (Syndfloden). Lindqvist fremhæver meget rigtigt, at netop "Potop" gav anledningen til, at polakkerne udviklede en særlig guerilla-teknik, som var meget effektiv overfor de svenske soldater. Det var ved at gå helt galt for svenskerne, da Frederik 3. af Danmark erklærede krig mod Sverige den 1. juni 1657. Så snart Karl X Gustav fik beskeden, kommanderede han "højre om", og få måneder efter stod han ved den danske grænse i Holsten, og den 26. februar 1658 måtte Danmark ved freden i Roskilde afstå Skåne, Halland og Blekinge samt halvdelen af Norge til Sverige. Den 8. august 1658 genoptog Karl Gustav krigen, men i mellemtiden havde Frederik 3. indgået alliancer med Polen, Brandenburg og Østrig, og en samlet allieret styrke rykkede op i Jylland i ryggen på svenskerne. De polske tropper blev ledet af den legendariske hetman Stefan Czarniecki. Polakkerne kæmpede godt, men hærgede også slemt og medbragte voldsomme epidemiske sygdomme, formentlig plettyfus. Afgørende blev deres indsats i slaget ved Nyborg på Fyn den 14. november 1659 under ledelse af oberst Piaseczyński, hvor svenskerne led et stort nederlag. Det førte igen til freden i København, hvor Danmark genvandt de afståede dele af Norge. Herman Lindquist gør ikke meget ud af felttoget til Danmark, men bruger til gengæld "Potop" til at illustrere, hvordan næsten hver generation af polakker brugte teknikken med at "gå under jorden« i kampen for frihed og selvstændighed - sidste gang i 1944. 


\section{6 | KARL-ERIK FRANDSEN}

Bogen er en nærmest tragisk beskrivelse af, hvordan polakkerne lige indtil 1989 med de frie valg og medlemskabet af NATO og EU er blevet mishandlet af nabostaterne, men bestemt også med en beundring af, hvordan de hver gang har rejst sig igen mod undertrykkerne. Man må håbe, at de også kan komme over Corona-krisen i 2020 og den deraf følgende indskrænkning af borgernes demokratiske rettigheder af præsident Jarosław Kaczyński. 